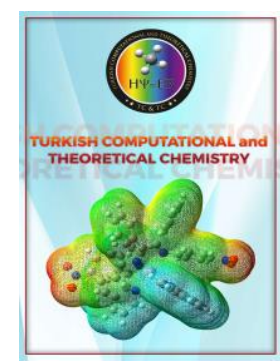

Received: 21.10 .2020
Turkish Computational and Theoretical Chemistry

Turkish Comp Theo Chem (TC\&TC)

Volume(Issue): 5(1) - Year: 2021 - Pages: 20-26

e-ISSN: 2602-3237

https://doi.org/10.33435/tcandtc.813939

Accepted: 01.02 .2021

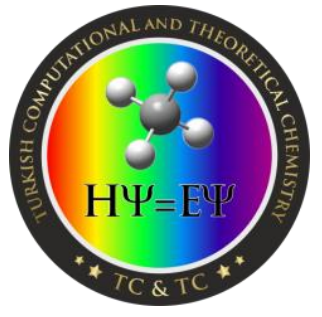

Research Article

\title{
The effective ethanol rate against the toxicity of ethylene glycol
}

\author{
Faik Gökalp ${ }^{1}$ \\ Department of Mathematics and Science Education, Faculty of Education, Kurlkkale University, 71450 \\ Kırlkkale, Turkey
}

\begin{abstract}
Ethylene glycol (EG) is a toxic substance and EG metabolites cause metabolic acidosis. The major emphasis in this study is to get rid of the toxicity of EG before conversion to its metabolites. The interaction between ethylene glycol and ethanol has been studied using DFT (Density functional theory method). In ethylene glycol metabolites in the blood; Glycolic acid is more stable and gloxal less stable. The interaction of ethylene glycol with ethanol has been considered for ethylene glycol metabolism. Thermodynamic values obtained from ethylene glycol metabolites and ethanol were also analyzed. According to the analyst results of ethanol and ethylene glycol ratios; The maximum effective point is very stable in the blood and its solubility is determined at this rate. It is very important to determine the most appropriate rate in the prevention of toxicity. This study is an important study in terms of the use of ethanol in the prevention of toxicity of EG, the first of its rates and in terms of preventing the loss of time and substance.
\end{abstract}

Keywords: Ethanol, density functional theory, ethylene glycol, glyoxal, blood

\section{Introduction}

Ethylene glycol is the most important chemical substance, having toxicity for the human body [1]. Especially, it is used as an antifreeze for automobile industrial products and it causes central nervous system depression and renal disorders [2]. A lot of studies related to the toxicity of ethylene glycol mechanism and its metabolites have been carried [3-7]. While being exposed of ethylene glycol as oral or skin, its destruction occurs in the liver [8]. Ethanol therapy may be applied to the patients previously with decreased serum ethylene glycol concentrations. While applying to the patient, the ethanol concentrations in blood were regarded as possible highly effective inhibition on ethylene glycol metabolism as assumed from normal acid/base parameters. However, the second application of ethanol was the result of respiratory arrest. During each application for that patient, hemodialysis formed the main road of ethylene glycol elimination [9-10].

Ethylene glycol is a toxic chemical found in antifreeze, heat exchangers and industrial areas. The standard applied therapy for its intoxication with ethanol to inhibit its metabolism by alcohol dehydrogenase (ADH). If ethylene glycol is higher in blood concentration, ethanol may be partially based on the dehydration and a low urine output with the inhibition of ADH metabolism [11]. It has been determined that there is a linear correlation between the binding energies of ethanol and ethylene glycol substances and the center of the surface d-band with increasing binding energy as the d-band center approaches the Fermi level [12]. Babak et al. the conclusion drawn from his study; At low ethylene glycol concentrations, hydrogen bonding between ethanol and ethylene glycol molecules and ethylene glycol at high concentrations revealed that ethanol as a solvent for ethylene glycol affects the reaction rate [13].The metabolites of ethylene glycol are given in Figure 1 $[7,8]$. In this study, the rate of the substance we will give to the metabolism without damaging against toxicity that occurs with ethylene glycol and which we may encounter in daily life is tried to be determined based on the computational methods.

\section{Materials and methods}

The first principles, including electronic structures and metabolites of EG, electronic correlation and

\footnotetext{
${ }^{1}$ Corresponding Authors

e-mail: akgokalp@gmail.com
} 


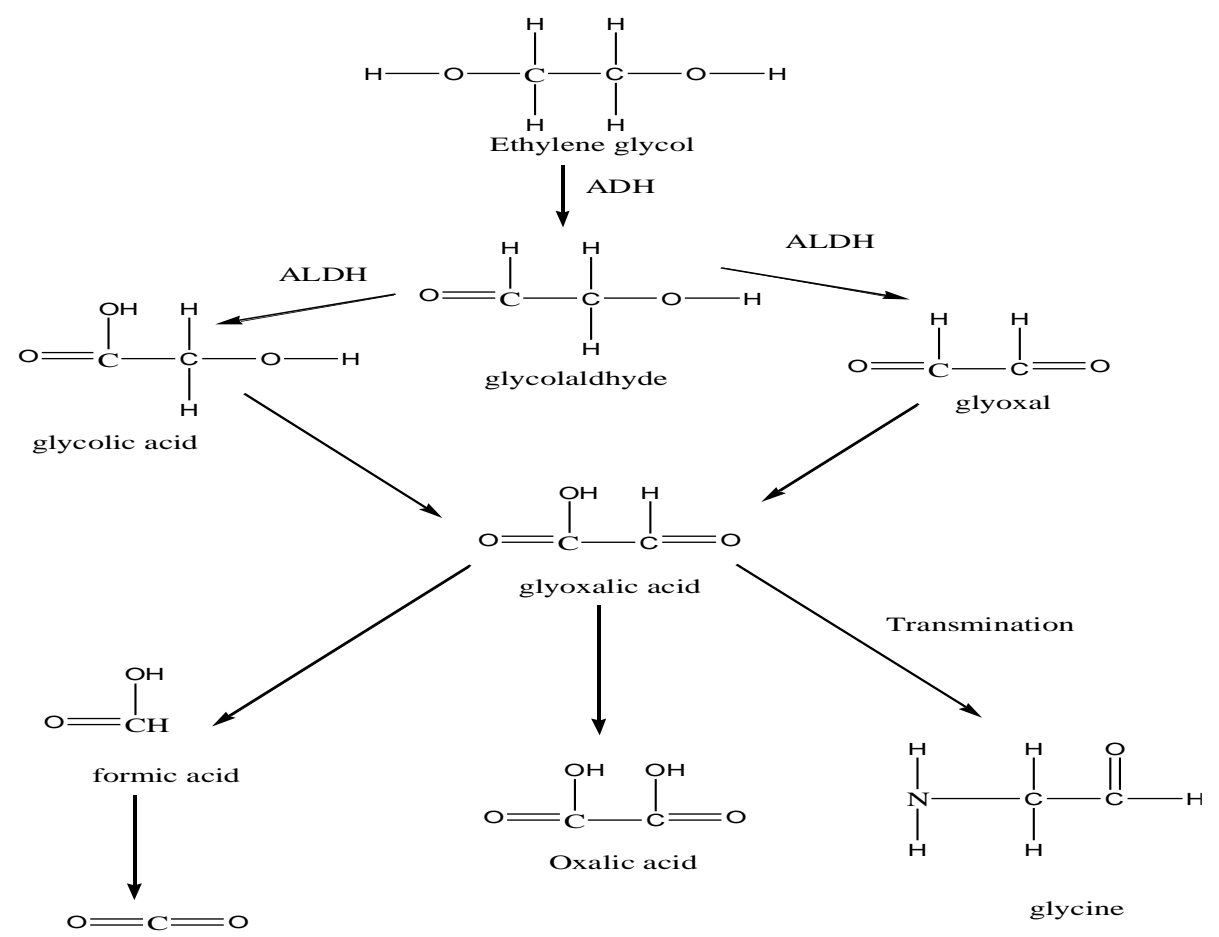

Figure 1. Methabolism of ethylene glycol [7,8]

spin trajectory corrections, were studied by theoretical methods. DFT, B3LYP methods are used for geometry optimization. Adjustments were made via $6-31+\mathrm{g}(\mathrm{d}, \mathrm{p})$ functional [28]. The thermodynamic values in blood have been calculated by using the DFT method, and the structure of the compounds was completely optimized and their geometric structures were determined and evaluated with these methods [17]. The structure of the compound has been optimized at the B3LYP / 6-31G (d, p) level [25,26]. According to information obtained from the literature for blood, its dielectric constant is 58 at 37 degrees Celsius [27].

\section{Results and discussion}

In Table 1; The Gibbs Free Energy, HOMO, LUMO, (HOMO-LUMO) differences and the metabolites of Ethylene glycol (Ethylene glycol, Glycoldiide, Glyoxal, Glycolic acid, Glyoxalic acid, Glycine, Formic acid, Carbon-dioxide, Oxalic acid) and dipole moments of ethanol in blood were given.

The energy required to remove an e- from the molecule is called the Ionization potential (I).

$$
\mathrm{I}=-\mathrm{E}_{\text {Hомо }}
$$

The ionization potential of Carbon Dioxide and Oxalic acid in blood using DFT are 0.38135, $0.31608 \mathrm{eV}$. Looking at the values in Table 1 , it is higher than the others.

Electron affinity (A) is the name given to the energy of a molecule attached to an e-.

$$
\mathrm{A}=-\mathrm{E}_{\text {LUMO }}
$$

Glyoxal's electron affinity in blood using DFT was $0.12425 \mathrm{eV}$. Looking at the values in Table 1; higher than others.

The electronegativity (X) of a molecule can be called its power to accept an electron.

Chemical hardness (n) is known as the difficulty of moving an electron in a molecule.

$$
\eta=\mathrm{I}-\mathrm{A} / 2 \text { [18]. }
$$

In Table 1; The chemical hardness of glycolic acid in blood using DFT is $0.143595 \mathrm{eV}$.

According to these values; Glycolic acid is the most stable molecule.

Chemical softness (n) is determined as the mobility of an electron in a molecule.

$$
S=1 / 2 \eta[19] .
$$


Table 1 The Gibbs Free Energy, HOMO, LUMO, $\Delta$ (HOMO-LUMO) and Dipole moments of Ethylene glycol's methabolities (Ethylene glycol, Glycolaldyde, Glyoxal, Glycolic acid, Glyoxalic acid, Glycine, Formic acid, Carbondioxid, Oxalic acid) and Ethanol in blood

\begin{tabular}{llllll}
\hline $\begin{array}{l}\text { DFT } \\
\text { (Ethylene glycol's } \\
\text { methabolities in } \\
\text { blood) }\end{array}$ & $\Delta \mathbf{G}$ (Hartree) & $\begin{array}{l}\text { HOMO } \\
(\mathbf{e V})\end{array}$ & $\begin{array}{l}\text { LUMO } \\
(\mathbf{e V})\end{array}$ & $\begin{array}{l}\Delta \text { (HOMO- } \\
\text { LUMO) }(\mathbf{e V})\end{array}$ & $\begin{array}{l}\text { Dipol moment } \\
\text { (Debye) }\end{array}$ \\
\hline Ethylene glycol & -230.22536 & -0.28880 & 0.00224 & -0.28576 & 0.00400 \\
\hline $\begin{array}{l}\text { Glycolaldyde } \\
\text { Glyoxal }\end{array}$ & -229.03408 & -0.28101 & -0.05306 & -0.22795 & 3.79040 \\
\hline Glycolic acid & -227.83110 & -0.28076 & -0.12425 & -0.15651 & 0.00020 \\
\hline Glyoxalic acid & -304.28594 & -0.30376 & -0.01657 & -0.28719 & 7.74040 \\
\hline Glycine & -303.08318 & -0.29673 & -0.11469 & -0.18204 & 6.35300 \\
\hline Formic acid & -209.15804 & -0.26198 & -0.04882 & -0.21316 & 3.99070 \\
\hline Oxalic acid & -189.77155 & -0.30859 & -0.02412 & -0.28447 & 5.22230 \\
\hline Carbondioxide & -378.34002 & -0.31608 & -0.09385 & -0.22223 & 6.67860 \\
\hline Ethanol & -188.60252 & -0.38135 & -0.01349 & -0.36786 & 0 \\
\hline & -155.009545 & -0.28289 & 0.07820 & -0.36109 & 2.2441 \\
\hline
\end{tabular}

In Table 1; The chemical softness of Glyoxal in the blood is determined as $6.389368 \mathrm{eV}$ using DFT. Glyoxal is the least stable and is the most reactive molecule of ethylene glycol metabolites in blood.

The chemical potential $(\mathrm{Pi})$ determined as the negative of electronegativity is calculated as $(\mathrm{X}) \mathrm{Pi}$ $=-(\mathrm{I}+\mathrm{A} / 2)$.

Also, some researchers have reported the electrophilic power of a molecule.

They expressed it as (= (Pi) $2 / 2 \eta[20-22]$.

In Table1; Electrophilic power of Glyoxal in blood using DFT, $1.04807 \mathrm{eV}$.

Glyoxal is the most electrophilic ethylene glycol metabolite in blood.

In their study; ethanol was used as an additive into ethylene glycol- $\mathrm{NaCl}$ electrolyte solutions to be adsorbed onto the surface of the electrode because of its polarity [14]. Ethanol was preferred for its many advantages such as lower toxicity, higher energy density [15]. The surface binding of ethanol and ethylene glycol was related to the $\mathrm{O}-\mathrm{H}$ bond cleavage [12]. The interaction of Ethylene glycol -Ethanol's values of HOMO, LUMO, $\Delta$ (HOMO-LUMO) and Dipole Moment by using DFT is given in Table 3.

The oxidation of the toxic alcohols such as methanol, ethylene glycol to $50 \mathrm{mM}$ was largely inhibited by $20 \mathrm{mM}$ ethanol [16]. At high ethylene glycol concentrations, ethanol appears to be involved as a solvent for ethylene glycol molecules, and it can be concluded that hydrogen bonding and hydrophobic interactions are between malachite green and alcohol molecules. [13]. The free energy values of Ethylene glycol -Ethanol rates in the blood phase are given in Table 2 .

The free energy values in Table 2: 0.00805 Hartree, 0.017874 Hartree, 0.014980 Hartree, The free energy values for Ethylene glycol -Ethanol separately and together;

We changed the rate of Ethanol; 1-Ethylene glycol -2-Ethanol (together) and 1-Ethylene glycol -2-Ethanol (separately) the free energy values were higher than the other. The results of the calculations; 1-Ethylene glycol -2-Ethanol (together), the value of 0.017874 , was the maximum effective point.

Pharmacologically, the toxicity of ethylene glycol is attributed to their metabolites causing severe acidosis and detected in patient plasma [23]. The interaction between Ethylene glycol -Ethanol

changes the electronic properties of the different species involved. When they come together; charge transference, structural modification and total energy values also change. As regards this, different ratios for Ethylene glycol -Ethanol in blood were studied by using B3LYP/6-31G(d,p) method to depict the different phases of the reaction.

According to datas from table 1; the difference between (Ethylene glycol + Ethanol ) and 1- 
Faik Gökalp

Ethylene glycol -2-Ethanol was 0.017874 Hartree, $11.21609 \mathrm{kcal}$. $\mathrm{mol}^{-1}$. Because of the hydrogen bonding between Ethylene glycol and Ethanol, the
Gibbs free energy of 1-Ethylene glycol -2-Ethanol changes as $11.21609 \mathrm{kcal}$. $\mathrm{mol}^{-1}$.

Table 2 The free energy values of Ethylene glycol -Ethanol rates in blood phase (The values are given as Hartree; 1 Hartree $=627.5095 \mathrm{kcal}^{\mathrm{mol}} \mathrm{mol}^{-1}$ ).

\begin{tabular}{|c|c|c|c|c|}
\hline $\begin{array}{l}\text { DFT (Blood) } \\
\text { (Separately) }\end{array}$ & $\begin{array}{l}\Delta \mathbf{G} \\
\text { Hartree }\end{array}$ & $\begin{array}{l}\text { DFT(Blood) } \\
\text { (Together) }\end{array}$ & $\begin{array}{l}\Delta \mathbf{G} \\
\text { Hartree }\end{array}$ & $\begin{array}{l}\Delta G(\text { Difference }) \\
\text { Hartree }\end{array}$ \\
\hline $\begin{array}{l}\text { 1Ethylene glycol + } \\
\text { 1Ethanol }\end{array}$ & -385.23491 & $\begin{array}{l}\text { 1Ethylene glycol - } \\
\text { 1Ethanol }\end{array}$ & -385.22686 & 0.008050 \\
\hline $\begin{array}{l}\text { 1Ethylene glycol + } \\
\text { 2Ethanol }\end{array}$ & -540.24446 & $\begin{array}{l}\text { 1Ethylene glycol - } \\
\text { 2Ethanol }\end{array}$ & -540.226586 & 0.017874 \\
\hline $\begin{array}{l}\text { 1Ethylene glycol + } \\
\text { 3Ethanol }\end{array}$ & -695.25401 & $\begin{array}{l}\text { 1Ethylene glycol - } \\
\text { 3Ethanol }\end{array}$ & -695.227300 & 0.026710 \\
\hline
\end{tabular}

On the other hand, the HOMO-LUMO difference of 1-Ethylene glycol -2-Ethanol was 0.28029 , It was indicated that 1-Ethylene glycol -2Ethanol was so stable, this stabilitywas from the formation of hydrogen bond between Ethylene glycol-ethanol This phenomenonwas emphasized from the literatüre [13-16]. But in this study; the rate of ethanol was determined exactly.Moreover, dipole moment of 1-Ethylene glycol-2-Ethanol was 3.69211. The solubility of 1-Ethylene glycol -2Ethanol was better than the others. The efficiencies of pharmacologicagents used in the treatment of both cardiac and noncardiac diseases were important assessments[29].

Table 3 The interaction of Ethylene glycol -Ethanol's values of HOMO, LUMO, $\Delta$ (HOMO-LUMO) and Dipole Moment By using DFT

\begin{tabular}{|c|c|c|c|c|c|}
\hline DFT (Blood) & $\begin{array}{l}\text { HOMO } \\
(\mathrm{eV})\end{array}$ & DFT(Blood) & $\begin{array}{l}\text { LUMO } \\
(\mathrm{eV})\end{array}$ & $\begin{array}{l}\Delta(\text { HOMO- } \\
\text { LUMO) } \\
(\mathrm{eV})\end{array}$ & $\begin{array}{l}\text { Dipol } \\
\text { moment } \\
\text { (Debye) }\end{array}$ \\
\hline $\begin{array}{l}\text { 1Ethylene glycol - } \\
\text { 1Ethanol }\end{array}$ & -0.28308 & $\begin{array}{l}\text { 1Ethylene glycol - } \\
\text { 1Ethanol }\end{array}$ & -0.00360 & -0.27948 & 2.25360 \\
\hline $\begin{array}{l}\text { 1Ethylene glycol - } \\
\text { 2Ethanol }\end{array}$ & -0.28290 & $\begin{array}{l}\text { 1Ethylene glycol - } \\
\text { 2Ethanol }\end{array}$ & -0.00261 & -0.28029 & 3.69211 \\
\hline $\begin{array}{l}\text { 1Ethylene glycol - } \\
\text { 3Ethanol }\end{array}$ & -0.27592 & $\begin{array}{l}\text { 1Ethylene glycol - } \\
\text { 3Ethanol }\end{array}$ & -0.00211 & -0.27381 & 3.6372 \\
\hline
\end{tabular}

In literatüre $[12,13]$ as mentioned above; The interaction between ethylene glycol and ethanol was the hydrogen bonding and ethanol in large quantity acted as a solvent. In this study; the rate of ethylene glycol and ethanol interaction was determined and hydrogen bond was shown in Fig3. HOMO and LUMO respectively; It can be defined as an electron donor and an electron acceptor, that is, molecules with high $\mathrm{E}_{\text {HOMO }}$ are good electron donors, while those with low $\mathrm{E}_{\mathrm{LuMO}}$ energy are good electron acceptors. [24]. So, the complexes of 1-Ethylene Glycol and 2-Ethanol were better electron-donor and electron-acceptor, respectively, than the other complexes. The negative results show that HOMO-LUMO energy gap values promisingly support the stability of the complexes of 1-Ethylene Glycol and 2-Ethanol. After the initial intoxication of ethylene glycol there could be progressive metabolic acidosis from the accumulation of acidic metabolites, caused to renal failure, rhabdomyolysis and Oxylate chelates with calcium,as a result of this there was hypocalcaemia and rhabdomyolysis. The main strategy for minimizing ethylene glycol toxicity was to the administration of ethanol as a competitive substrate [30,31]. The inhibition of Oxalic acid was to important to protect the damage of E.G. The important point of the treatments of Ethylene Glycol ingestions was that the hemodialysis is to prevent irreversible kidney injury by limiting the ultimate metabolism of EG to oxalate [32]. The toxicity of E.G.was from the production of the acidic metabolites glycolate and oxalate [33]. The accuracy of the method used has been confirmed by the other studies [34-37]. 
Faik Gökalp

Ethanol can dissolve in the blood and reach the tissues of body systems. Especially ethylene glycol poisoning in the blood; Ethanol has an effective role against ethylene glycol toxicity by forming a stable structure with ethanol and its effective rate against toxicity has been determined as shown in the discussion section.

\section{Conclusion}

In metabolites of ethylene glycol in the blood; glyoxal is less stable, but its dipole moment is quite low, meaning its solubility in the blood is smaller than others, but its solubility in oxalic acid is better than others. Oxalic acid is very harmfulto kidney diseases. Ethylene glycol is toxic to the metabolism of the human body due to its metabolites. Therefore, it must be removed from metabolism without separating into metabolites. In this study, in EG poisoning, rapid removal by using ethanol; The capacity of ethanol to remove ethylene glycol, the ratio of 1-Ethylene glycol -2-Ethanol was determined. Moreover, at this rate; Since it has a high dipole moment, it is more stable and dissolves in blood. This rate in preventing toxicity is vital for human metabolism. The experimental researchers should try and make them viable by using these theoretical results, This study is very important in terms of preventing loss of time and material.

\section{Acknowledgment}

The calculations made here were made using Kirıkkale University Information Technology Center and Gaussian 09W64 programs. This study is supported within the scope of Kirikkale University Scientific Research Projects (BAP2016/016,2017/019).

\section{References}

[1] R.A. Corley, Meek,M.E. ,E.E. Carney, Mode of action:Oxalate crystal-induced renal tubule degeneration and glycolic acid-induced dysmorphogenesis Renal developmental effects of ethylene glycol,Crit.Rev.Toxicol. 35 (2005) 691-702.

[2] A.F.Eder, C.M. McGrath, Y.G. Dowdy, J.E. Tomaszewski, F.M. Rosenberg, R.B. Wilson, B.A. Wolf, L.M. Shaw,Ethylene glycol poisining:Pharmocokinetic and analytical factors affecting laboratory diagnosis,Clin.Chem.44 (1998) 168-177.
[3] G.,Coen, B.,Weiss, Oxidation of ethylene glycol to glycolaldyde by mammalian tissues,Enzymol Biol.Clin.6 (1966) 288-296.

[4] T.C., Marshall, Dose dependent disposition of ethylene glycol in the rat after intravenous administration,J.Toxicol Environment Health, 10 (1982) 397-409.

[5] E.W., Carney, An integrated perspective on the developmental toxicity of ethylene glycol,Repr. Toxicol Rev.8 (1994) 99-113.

[6] E.W., Jeffrey, Current management of ethylene glycol poisoning,Drugs. 61 (2001) 979-988.

[7] F.,Huq, D., Ababneh, Moleculer modelling analysis of the metabolic activation of ethylene glycol,J.of Pharmacology and Toxicology. 2-1 (2007) 54-62.

[8] E.D., Booth, O. Dofferhoff, P.J. Boogaard, W.P. Watson, Comparison of the metabolism of etylene glycol and glycolic acid in vitro by precision cut tissue slices from female rat,rabbit and human liver,Xenobiotica. 34 (2004) 31-48.

[9] P.K., Gessner, D.V. Parke, R.T. Williams, The metabolism of C-14-labelled ethylene glycol,Biochemical.79 (1961) 482-489.

[10] M., Kowalczyk, S. Halvorsen, S. Ovrebo, J. E. Bredesen, D. Jacobsen, Ethanol treatment in ethylene glycol poisoned patients, Veterinary and Human Toxicology , 40- 4 (1998) 225 - 228.

[11] S. K., Cox, Ferslew, K. E., L. J. Boelen, The toxicokinetics of 1,3-butylene glycol versus ethanol in the treatment of ethylene glycol poisoning, Veterinary and Human Toxicology. 34- 1 (1992) 36-42.

[12] S., Orest, A. Mark, J. Barteau, G. Chen, Ethanol and ethylene glycol on $\mathrm{Ni} / \mathrm{Pt}(111)$ bimetallic surfaces: A DFT and Hreels study, Surface Science, 602 (2008) 3578-3587.

[13] S., Babak, A. Somayeh, Study of Malachite Green Fading in Water-Ethanol- Ethylene Glycol Ternary Mixtures, J. Solution Chem. 42 (2013) 151-164.

[14] D., Kima, K. Sonb, D. Sung, Y. Kim, W. Chunga,Effect of added ethanolinethyleneglycol-NaClelectrolyteon titanium electropolishing, Corrosion Science, 98 (2015) 494-499.

[15] O. F., Omobosede, I. O Kenneth, 
Faik Gökalp

Comparative electrocatalytic oxidation of ethanol, ethylene glycol andglycerol in alkaline medium at Pd-decorated FeCo@Fe/C core-shellnanocatalysts, Electrochimica Acta. 128 (2014) 279-286.

[16] L., Shou-Lun, S. Hsuan-Ting C. Yu-Chou, L Yeung-Pin, Y. Shih-Jiun,Oxidation of methanol, ethylene glycol, and isopropanol with human alcohol dehydrogenases and the inhibition by ethanol and 4-methylpyrazole, Chemico-Biological Interactions. 191 (2011) 26-31.

[17] F., Gökalp, An investigation of the olive phenols activity as a natural medicine, Journal of Food and Drug Analysis. 26 (2018) 65 7661.

[18] R. Pearson, Absolute electronegativity and hardness: applications to organic chemistry, J. Org.Chem. 54 (1989) 1423-1430.

[19] R. G. Pearson, Proceeding of the National Academiy of Sciences, 83 (1986) 8440-8441.

[20] B. Gómez, N. V. Likhanova, M. A. Domínguez Aguilar, O. Olivares, J. M. Hallen, and J. M. Martínez-Magadán, Theoretical Study of a New Group of Corrosion Inhibitors, Journal of Physical Chemistry A, 109-39 (2005) 8950-8957.

[21] P.K. Chattaraj, Chemical Reactivity Theory: A Density Functional View, 610 (2009) CRC Press, New York.

[22] A. Eşme, S. G. Sağdınç, The linear, nonlinear optical properties and quantum chemical parameters of some sudan dyes, BAÜ The Institutaion Of Science. 16-1 (2014) 47-75 .

[23] D. J. Orton, J. M. Boyd, D. Affleck, D. Duce, W. Walsh, I. Seiden-Long, One-step extraction and quantitation of toxic alcohols and ethylene glycol in plasma by capillary gas chromatography (GC) with flame ionization detection (FID). Clinical biochemistry. 49 (2016) 132-138.

[24] P. Gurumoorthy, D. Mahendiran, A.K. Rahiman, Theoretical calculations, DNA interaction, topoisomerase I and phosphatidylinositol-3-kinase studies of water soluble mixed-ligand nickel(II) complexes, Chemico-Biological Interactions. 248 (2016) 21-35.

[25] Gaussian 09, Revizyon E.01, M. J.; Frisch, Trucks, G. W.; Schlegel, H. B.; Scuseria, G.
E.; Robb, M. A.; Cheeseman, J. R.; Scalmani, G.; Barone, V.; Mennucci, B.; Petersson, G. A.; Nakatsuji, H.; Caricato, M.; Li, X.; Hratchian, H. P.; Izmaylov, A. F.; Bloino, J.; Zheng, G.; Sonnenberg, J. L.; Hada, M.; Ehara, M.; Toyota, K.; Fukuda, R.; Hasegawa, J.; Ishida, M.; Nakajima, T.; Honda, Y.; Kitao, O.; Nakai, H.; Vreven, T.; Montgomery, J. A., Jr.; Peralta, J. E.; Ogliaro, F.; Bearpark, M.; Heyd, J. J.; Brothers, E.; Kudin, K. N.; Staroverov, V. N.; Keith, T.; Kobayashi, R.; Normand, J.; Raghavachari, K.; Rendell, A.; Burant, J. C.; Iyengar, S. S.; Tomasi, J.; Cossi, M.; Rega, N.; Millam, J. M.; Klene, M.; Knox, J. E.; Cross, J. B.; Bakken, V.; Adamo, C.; Jaramillo, J.; Gomperts, R.; Stratmann, R. E.; Yazyev, O.; Austin, A. J.; Cammi, R.; Pomelli, C.; Ochterski, J. W.; Martin, R. L.; Morokuma, K.; Zakrzewski, V. G.; Voth, G. A.; Salvador, P.; Dannenberg, J. J.; Dapprich, S.; Daniels, A. D.; Farkas, O.; Foresman, J. B.; Ortiz, J. V.; Cioslowski, J.; Fox, D. J. Gaussian 09, Revision C.;01 (2010).

[26] P. Zhao, S.X. Cao, Y.C. Guo, P. Gao, Y.Y. Wang, M.M. Peng, Y.F, Zhao, Investigation of the $\mathrm{C}-\mathrm{N}$ bond rotation of spirophosphorane carbamates by dynamic NMR and DFT calculation,Tetrahedron. 71(46) (2015) 8738 -8745 .

[27] https://www.microwaves101.com/encycloped ias/miscellaneous-dielectric-constants (2018), 11 April.

[28] F., Gökalp, A Study On The Chemical Properties Of Eugenol And Eugenol Acetate, Clove Essential Oils, Sigma J Eng \& Nat Sci. 34 (3) (2016) 407-414.

[29] S. Phungphong, A.Kijtawornrat, P.P. Tombe, J. Wattanapermpool,J, Bupha-Intr, T. Suksamrarn, S. Acute, inhibitory effect of alpha-mangostin on sarcoplasmic reticulum calcium-ATPase and myocardial relaxation. J Biochem Mol Toxicol. (2017)31:e21942.

[30] K. McMartin, D. Jacobsen, K.E. Hovda, Antidotes for poisoning by alcohols that form toxic metabolites. Br J Clin Pharmacol. 81 (2016) $505 \mathrm{e} 15$.

[31] W. S., Waring, Alcohols and glycols poisoning, Poisonous Substances.48-3 (2020) 185-188.

[32] D. Matthew, M.D. Krasowski, Educational 
Faik Gökalp

Case: Ethylene Glycol Poisoning, Academic Pathology. 7 (2020).

[33] P. Dibajnia, L.A. M. Sivilotti, D. Juurlink, M. Shurrab, ST-elevation in ethylene glycol toxicity mimicking myocardial infarction, Journal of Electrocardiology. 58 (2020) 128131.

[34] F.Gökalp, The chemical activity of Juglone in different phases as a protective agent, Journal of Fluorine Chemistry. 242 (2021) 109701.

[35] F.Gökalp, An Investigation into the Usage of Monosaccharides with GLUT1 and GLUT3 as Prognostic Indicators for Cancer, Nutrition and Cancer. (2021) 1-5.

[36] F.Gökalp, A theoretical investigation of TNT in different phases by using DFT, Turkish Computational and Theoretical Chemistry.3-1 (2019) 1-4.

[37] F.Gökalp,T.A.Demir, A Theoretical Study On The Chemical Activities Of The Mainly Oregano Essential Oils,3-2 (2019) 86-91. 